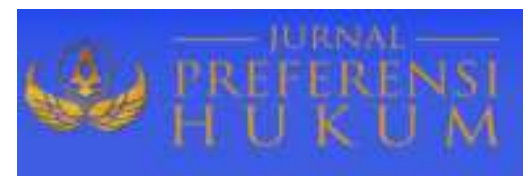

Jurnal Preferensi Hukum | ISSN: 2746-5039

Vol. 2, No. 2 - Juli 2021, Hal. 332-336| Available online at

https://www.ejournal.warmadewa.ac.id/index.php/juprehum

DOI: https://doi.org/10.22225/jph.2.2.3330.332-336

\title{
PERLINDUNGAN HUKUM TERHADAP WHISTLEBLOWER DALAM TINDAK PIDANA NARKOTIKA
}

\author{
Gusti Nyoman Adung Setiawan, Anak Agung Sagung Laksmi Dewi, I Made Minggu Widyantara \\ Fakultas Hukum, Universitas Warmadewa, Denpasar-Bali, Indonesia \\ ladungsetiawan037@gmail.com, laksmidewi29@gmail.com, Emailmademinggu@gmail.com
}

\begin{abstract}
Abstrak
Wistleblower adalah seseorang yang menyadari akan adanya suatu perbuatan pidana dan memberitahukannya kepada aparat penegak hukum. Peran whistleblower sangat penting membantu bagi pembeberan perbuatan penyalahgunaan narkotika. Tujuan dari penelitian ini yaitu untuk mengetahui pengaturan perlindungan hukum terhadap whistleblower dalam penyalahgunaan narkotika serta untuk mengetahui perlindungan hukum terhadap whistleblower dalam tindak pidana narkotika. Metode penelitian yang digunakan dalam penelitian ini adalah metode penelitian hukum normatif normative legal research method yang dilakukan dengan mengkaji sebuah peraturan peraturan perundang-undangan yang berkaitan dengan permasalahan yang sedang dibahas serta melalui pendekatan konseptual atau conceptual approach yang dimana menunjukan pada sebuah konsep, serta menggunakan sebuah doktrin yakni sebuah pandangan atau pemikiran para ahli yang terkait dengan ilmu hukum. Orang yang merupakan whistleblower atau pemberitahu dalam penyalahgunaan narkotika selalu menanggung balasan balik dari golongan yang merasa diberatkan atau dirugikan hasil dari pemberitahuan atau laporan dari whistleblower, Keamanan hukurn bagi seorang yang merupakan pelopor atau whistleblower dalam menyidik tindak pidana penyalahgunaan narkotika penting diberikan pada pihak berwenang supaya semua orang rela menjadi pelapor demi mendukung lembaga hukum mengungkap dan menangkap penyalahgunaan narkotika. Keamanan bagi whistleblower harus dibuatkan secara tegas dalam undang-undang agar keamanan kepada whistleblower bias ditegakan.
\end{abstract}

Kata kunci: Perlindungan Hukum, Tindak Pidana Narkotika, Whistleblower.

\begin{abstract}
A wistleblower is someone who is aware of a criminal act and notifies it to law enforcement officials. The role of whistleblowers is very important to help expose acts of narcotics abuse. The purpose of this study is to determine the legal protection arrangements for whistleblowers in narcotics abuse and to find out legal protection for whistleblowers in narcotics crime. The research method used in this research is normative legal research method normative legal research method which is carried out by examining a statutory regulation related to the problem being discussed and through a conceptual approach or conceptual approach which shows a concept, and uses a conceptual approach. Doctrine, namely the views or thoughts of experts related to the science of law. A person who is a whistleblower or notifier in narcotics abuse always bears a reply from those who feel aggrieved or aggrieved as a result of a notification or report from a whistleblower, legal security for a person who is a pioneer or whistleblower in investigating criminal acts of narcotics abuse is important given to the authorities so that all people are willing to become reporters in order to support legal institutions to reveal and arrest narcotics abuse. Security for whistleblowers must be made strictly in law so that security for whistleblowers can be upheld.
\end{abstract}

Keywords: Legal Protection, Narcotics Crime, Whistleblower.

\section{PENDAhuluan}

Indonesia sebagai salah satu Negara kepulauan terbesar di dunia dikelilingi oleh berbagai jalur perdagangan lintas Negara baik dalam skala besar maupun kecil. Keberadaan jalur perdagangan tersebut tidak hanya membawa dampak berbagai positif bagi keberlangsungan Negara, namun juga turut membawa dampak negatif. Lancarnya arus perputaran ekonomi menjadi salah saru indikator yang menunjukkan dampak positif dari keberadaan jalur perdagangan tersebut, namun sebaliknya banyak oknum nakal yang menggunakan jalur perdagangan lintas Negara sebagai celah untuk melakukan kejahatan luar biasa extraordinary crime yakni dengan mendatangkan narkotika dari luar negeri dan memperdagangkannya di Indonesia. Alhasil, Indonesia termasuk sebagai salah satu tempat lintas narkotika internasional dengan sifat jejaring expansif hingga ke seluruh wilayah Indonesia, bahkan jalur-jalur perdagangan Indonesia sering dijadikan transit point oleh para pelaku sebelum narkotika 
sampai di tempat tujuan (Negara lain). Hal ini berdarnpak pada masifnya peredaran narkotika di dalam negeri dari tahun ke tahun. Luasnya peredaran narkotika ilegal di dalam negeri memicu skala langka penyalahgunaan narkotika, sebagaimana data survei Badan Narkotika asional (BNN) yang menunjukkan peningkatan kasus penyalahgunaan narkotika dari tahun ke tahun, dimana tercatat pada tahun 2019 terdapat sejumlah 46.357 kasus penyalahgunaan narkotika yang tersebar di seluruh wilayah Indonesia. Menindaklanjuti fakta buruk narkoba yang terjadi belakangan ini, Indonesia telah meratifikasi konvensi United Nations Convention Against Illicit Traffic in Narcotic Drugs and Psychotropic Substances, 1998, yang diratifikasi melalui Undang-undang Dasar Negara Republik Indonesia Nomor 7 Tahun 1997 mengenai Persetujuan Konvensi Perserikatan Bangsa-Bangsa atau PBB tentang Pemberantasan Peredaran Gelap Narkotika dan Psikotropika di Indonesia.

Narkotika adalah obat atau zat yang dapat menenangkan syaraf, mengakibatkan ketidaksadaran, atau pembiusan, menghilangkan rasa nyeri dan sakit, menimbulkan rasa mengantuk atau merangsang, dapat menimbulkan efek stupor, serta dapat menimbulkan adiksi atau kecanduan, dan yang ditetapkan oleh Menteri kesehatan sebagai Narkotika (Mardani, 2008 : 18). Narkoba mempunyai dampak negatif yang sangat luas; baik secara fisik, psikis, ekonomi, sosial, budaya, hankam, dan lain sebagainya. Bila penyalahgunaan narkoba tidak diantisipasi dengan baik maka akan rusak bangsa dan negara ini. Oleh karena itu, diperlukan kerja sama yang baik dari seluruh komponen bangsa untuk penanggulangan penyalahgunaan narkoba (Soedjono, 2000: 41). Setiap pecandu narkoba setiap saat membutuhkan narkotika sebagai bagian dari kebutuhan hidupnya yang cenderung dosisnya akan selalu bertambah, dibandingkan dengan dengan beberapa barang dagangan lainnya, narkotika adalah komoditi yang menguntungkan, meskipun ancaman dan resikonya cukup berat (Sitanggang, 1999: 32).

Tindak pidana mengkonsumsi, mengedarkan dan menyimpan dalam sudut pandang hukum pidana Indonesia termasuk kedalam kejahatan luar biasa atau extraordinary crime karena kejahatan narkotika dilakukan secara terorganisir, sisternatis dan rahasia dalam serangkaian modus operandi yang kompleks, pemanfaatan teknologi canggih, jaringan yang luas di berbagai daerah. Kemudian kejahatan narkotika berdampak terhadap seluruh aspek kehidupan masyarakat yang meliputi aspek hukum, ekonomi, sosial dan budaya serta merusak kesehatan fisik maupun mental generasi penerus bangsa. Dalam rangka mengungkap tabir kejahatan narkotika yang begitu terorganisir, dibutuhkan suatu metode penyelidikan yang dapat dijadikan pedoman oleh penegak hukum dalam mengungkap jaringan peredaran gelap narkotika dan memberantas tindak pidana narkotika. Metode tersebut dikenal dengan nama whist/eblower.lstilah whistleblower belakangan ini kerap dikenal dan cukup populer di kalangan akademisi hukum dan praktisi hukum.

Whistleblower umumnya diberikan oleh seseorang yang pertama kali memberitahu atau mengungkap perbuatan pidana narkotika di suatu tempat yang memiliki kaitan dengan dirinya, kepada otoritas berwenang dalam pengungkapan kejahatan yang melibatkan kolega, teman bahkan atasannya sendiri. Untuk dapat disebut sebagai seorang whistleblower, maka harus memenuhi dua kriteria sebagai berikut a. Pertama, seorang whistleblower melaporkan kepada aparat atau otoritas berwenang maupun kepada publik dengan harapan agar dugaan kejahatan narkotika dapat terungkap b. Kedua, seorang yg merupakan whistleblower ialah orang dalam, yakni seseorang yang memberitahu suatu penyalahgunaan narkotika yang berlangsung di perusahaan ia bekerja atau dalam jaringan pekerjaan. Perkembangan ide whistleblower bagi pengungkapan tindak pidana didasari oleh ketentuan pasal 26.

United Nations Convention Against Transnational Organized Crimes tahun 2000, sebagaimana telah diratifikasi melalui Undang-Undang Dasar No 5 Tahun 2009. Whistleblower secara yuridis telah mendapatkan perlindungan, sebagaimana tertuang secara implisit dalam Undang-Undang Dasar Negara Republik Indonesia No 31 Tahun 2014 berkaitan dengan Perubahan atas UU No 13 Tahun 2006 atas Perlindungan Saksi dan Korban. Pengaturan whistleblower yang lebih komprehensif dapat ditemukan pada Surat Edaran Mahkamah Agung Nomor 4 Tahun 2011 serta dalam Peraturan Bersama tentang Perlindungan bagi pelapor, Saksi Pelapor dan Saksi Pelaku yang Bekerjasama. Dalam SEMA No. 4 Tahun 2011 menyatakan bahwa whistleblower atau pelapor tindak pidana merupakan pihak yang tahu dan memberitahukan perbuatan pidana tertentu dan tidak merupakan anggota bagi pelaksana perbuatan pidana yang diberitahukan. Bagi kasus tindak pidana narkotika, seorang whistleblower yang berani rnelaporkan dan memberikan kesaksiannya dalam kasus narkotika memiliki keberanian, pemikiran dan mental yang kuat, sebab orang tersebut sudah mengetahui resiko buruk serta kerugian yang mengancam dirinya atas laporan tersebut baik secara materil maupun immaterial. Sehingga dirasa penting untuk memberikan perlindungan hukum seorang whistleblower agar dapat memberi keterangan di muka 
persidangan tanpa rasa takut ataupun terbebani. Melihat peran whistleblower yang begitu penting bagi aparat penegak hukum dalam pengungkapan tindak pidana narkotika, maka sudah sewajarnya whistleblower mendapatkan perlindungan hukurn guna melindungi hak-hak whistleblower dari tindak pidana lain yang mengancam dirinya, berasal dari kekuatan jaringan ekstemal pelaku, karena dianggap seorang whistleblower merugikan pelaku yang selama ini meraup untung besar dalam lingkaran hitam kejahatan narkotika. Jika tidak ada kepastian dan keamanan hukum yang bagus terhadap whistleblower bahwa peran publik dalam memberantas tindak pidana narkotika akan berada di titik rendah, berbanding terbalik dengan angka kejahatan narkotika yang semakin meningkat.

Penelitian ini tidak luput dari beberapa penelitian yang serupa untuk dijadikan sebagai acuan dalam penyusunan penelitian. Adapun peneliti sebelumnya membahas tentang: Isti Latifah Astri, Sidik Sunaryo, Bayu Dwi Widdy Jatmiko "Perlindungan Hukum Terhadap Justice Collaborator dalam Tindak Pidana Narkotika" Fakultas Hukum, Universitas Muhammadiyah Malang. Kadek Yolanda Zara Octavany, Ni Ketut Sri Utar "Eksistensi dan Perlindungan Hukum Terhadap Whistleblower Dan Justice Collaborator dalam Upaya Penanggulangan Organized Crime di Indonesia pada Masa Mendatang" Fakultas Hukum Universitas Udayana. Fransiska Novita Eleanora "Bahaya Penyalahgunaan Narkoba Serta Usaha Pencegahan dan Penanggulangannya" Universitas Mpu Tantular Jakarta.

Berdasarkan penjelasan diatas dapat disimpulkan tujuan dari penelitian ini yaitu untuk mengetahui pengaturan perlindungan hukum terhadap whistleblower dalam penyalahgunaan narkotika serta untuk mengetahui perlindungan hukum terhadap whistleblower dalam tindak pidana narkotika.

\section{METODEPENELITTAN}

Metode ini digunakan pada penulisan penelitian ini dengan menggunakan metode penelitian hukum normatif normative legal research method yang dilakukan dengan mengkaji sebuah peraturan peraturan perundang-undangan yang berkaitan dengan permasalahan yang sedang dibahas serta melalui pendekatan konseptual atau conceptual approach yang dimana menunjukan pada sebuah konsep, serta menggunakan sebuah doktrin yakni sebuah pandangan atau pemikiran para ahli yang terkait dengan ilmu hukum. (Soerjono Soekanto dan Sri Mamuji, 2010: 13-14) Penelitian normatif atau disebut juga penelitian hukum kepustakaan adalah penelitian hukum yang dilakukan dengan cara meneliti bahan pustaka atau bahan sekunder belaka. Dengan menggunakan sumber bahan hukum yang meliputi bahan hukum primer, bahan hukum sekunder, dan bahan hukum tersier. Dalam menghimpun bahan menggunakan metode srudi pustaka yakni dengan berbagai buku, jurnal, serta berbagai literatur yang berkaitan dengan permasalahan yang dibahas dalam pokok bahasan penulisan jumal ini serta dalam pengolahan bahan tersebut menggunakan metode deskripsi dengan melihat peristiwa yang terjadi dalam kehidupan bermasyarakat dan bemegara. Serta menggunakan bahan hukum primer yang mengacu pada Peraturan Perundang-Undangan yang digunakan yaitu United Nations Convention Against Transnational Organized Crimes sebagaimana tel ah diratifikasi melalui undang-Undang Nomor 5 Tahun 2009 Tentang Konvensi PBB Anti Kejahatan Transnasional Terorganisir. Undang-Undang Nomor 35 Tahun 2009 tentang arkotika Peraturan Pemerintah Nomor 40 tahun 2013 ten tang Pelaksanaan Undang-Undang Nornor 35 Tahun 2009 tentang Narkotika Undang-Undang Nomor 31 Tahun 2014 tentang Perubahan Atas Undang-Undang Nomor 13 Tahun 2006 tentang Perlindungan Saksi dan Korban. Dalam penulisan jurnal ini menggunakan berbagai literarur serta jurnal ilmiah yang terkait dengan rumusan masalah yang dibahas sedangkan bahan hukum tersier menggunakan bahan hukum sebelumnya sebagai perbandingan yang menunjang penulisan jurnal ilmiah ini.

\section{HASIL DAN PEMBAHASAN}

\section{Pengaturan Perlindungan Hukum Terhadap Whistleblower dalam Tindak Pidana Narkotika}

Keamanan hukum bagi whistleblower atau pemberitahu atau pelapor tindak pidana tertenru yairu pemikirannya perlu diberikan hak yang dipergunakan oleh mereka pada saat posisinya diproses di persidangan pidana. Keamanan hukum atau perlindungan hukum ini adalah bagian hadiah atau penghargaan bagi partisipasi mereka dalam perjalanan ini. Sejalan dengan itu dalam pasal 28 huruf $\mathrm{g}$ UUD 1945 juga telah mengamanatkan pentingnya perlindungan bagi warga Negara.

Berkaitan dengan beberapa peraturan yang mengatur perlindungan dan keamanan hukum terhadap whistleblower dan eksistensi dari whistleblower dalam tindak Narkotika itu sendiri, pada dasarnya belum secara komprehensif diarur sehingga belum mendapatkan perlindungan secara yuridis 
normatif terhadap whistleblower itu sendiri. Perlindungan dan keamanan hukum bisa diartikan sebagai setiap bentuk perlindungan yang diatur dan didasarkan oleh peraruran dan perundang-undangan berdasarkan legalitas daripada hukum. Pengamanan hukum bagi whistleblower secara menyeluruh sebaiknya berlangsung bagi semua proses hukum di peradilan yang berlaku (pemberitahuan, pemeriksaan, pengusutan, penggugatan, dan analisis di pertemuan dalam persidangan) kendati sesudah tahapan peradilan beres. (Lilik Mulyadi, 2007)

Seorang whistleblower layak dianugerahkan pengamanan dan keamanan yang cukup berdasarkan keterangannya kemudian ia tidak merasakan sesuatu yang membahayakan atau mengintimidasi baik hak maupun jiwanya serta juga terlibat keluarganya karena keamanan dan kenyamanan terhadap keluarga mereka tentunya akan berpengaruh pada saat menjalankan fungsi sebagai pelapor dan mengungkap fakta daJam tindak pidana narkotika. Jaminan pengamanan hukum dan keamanan hukum iru diperlukan suatu situasi yang mengharuskan orang-orang tidak lagi berpikir khawatir untuk memberitahukan suaru perbuatan tindak pidana yang ditemukan kepada aparat hukum yang berwenang karena takut atau gelisahjiwa dan mentalnya terancam dari kelompok khusus.

Perlindungan dan keamanan hukum mempunyai makna sebagai perlindungan dengan menggunakan sarana hukum atau perlindungan yang diberikan oleh hukum, dirujukan kepada perlindungan terhadap kepentingan-kepentingan tertentu, yaitu dengan cara menjadikan kepentingan yang perlu dilindungi tersebut kedalam sebuah hak hukum dan tentang fungsi hukum untuk memberi keamanan yaitu hukum itu ditumbuhkan dan dibutuhkan oleh semua individu (Lili Rasjidi, 2002).

Perlindungan hukum dapat dibagi menjadi 2, yaitu ada perlindungan Hukum Preventif, perlindungan yang diberikan oleh pemerintah dengan tujuan untuk mencegah sebelum terjadinya pelanggaran. Hal ini terdapat dalam peraturan perundang-undangan dengan maksud unruk mencegah suatu pelanggaran serta memberikan rambu-rambu atas batasan-batasan dalam melakukan suaru kewajiban dan perlindungan represif, perlindungan akhir berupa sanksi denda , penjara, dan hukum tambahan yang diberikan apabila sudah terjadi sengketa atau telah dilakukan suatu pelanggaran (Satjipto Rahardjo, 2000).

Berdasarkan uraian tersebut diatas dapat diketahui bahwa perlindungan hukum adalah segala bentuk upaya pengayoman yang diberikan oleh Pemerintah terhadap harkat dan martabat manusia serta pengakuan terhadap hak asasi manusia dibidang hukum. Dalam penelitian ini, perlindungan hukum diberi batasan sebagai suatu upaya yang dilakukan dibidang hukum dengan maksud dan tujuan memberikan jaminan perlindungan terhadap pelapor tindak pidana tertentu atau whistleblower demi mewujudkan tujuan hukum itu sendiri. Whistleblower secara tekstual dan tersurat diatur dalam SEMA no. 4 Tahun 201 1.Dalam SEMA tersebut whistleblower diartikan sebagai pelapor tindak pidana. Pelapor tindak pidana yang dimaksud oleh SEMA ini adalah mereka yang mengetahui dan melaporkan tindak pidana tertentu sebagaimana dijelaskan SEMA memiliki dua kapasitas atau peran yaitu sebagai pelapor yang hanya sebatas melaporkan suatu tindak pidana tertentu dan bias juga pelapor tersebut tidak hanya ebata bertugas melaporkan saja tetapi juga berperan sebagai saksi. Secara teknis, pelapor tindak pidana baik yang berperan sebagai pelaporan maupun sebagai saksi sekaligus, sebagai tidak mengatur secara detail dan komprehensif terkait perlindungan apa saja yang dapat diberikan kepada mereka.

Kualifikasi whistle blower yang merangkap sebagai pelapor dan sebagai saksi ini, harus dibedakan dengan pengertian umum tentang pelapor dan saksi secara umum. Dengan adanya perbedaan kualifikasi saksi pelapor dengan pelapor dan saksi dalam pengertian umum (yang bukan whistleblower), akan tampak juga perbedaan mereka masing-rnasing dalam proses peradilan pidana. Berdasarkan ketentuan umum Pasal I angka 5 UU No. 13 Tahun 2006 jo UU No. 31 Tahun 2014 , memberikan definisi untuk LPSK yang menyatakan yaitu Lembaga Perlindungan Saksi dan Korban yang selanjutnya disingkat LPSK adalah Lembaga yang bertugas dan berwenang untuk memberikan perlindungan dan hak-hak lain kepada saksi dan/atau korban sebagaimana diatur dalam Undang-Undang.

Tugas dan kewenangan dari LPSK diatur dalam UU. No. 13 Tahun 2006 jo UU No. 31 Tahun 2014 , dimana tugas yang paling utama dari LPSK itu sendiri adalah memberikan perlindungan dan rasa aman kepada korban dan saksi termasuk pelapor yang rnengetahui tindak pidana dalam memberikan keterangan pada setiap proses peradilan pidana agar tercipta penegakan hukum yang adil dan tidak adanya keberpihakan . Perlindungan dalam UU No. 31 Tahun 2014 diartikan sebagai upaya pemenuhan hak dan pemberian bantuan unruk rnemberikan rasa aman kepada korban, saksi dan/atau pelapor tindak pidana yang wajib dilaksanakan oleh LPSK. 
Tugas dan kewenangan yang dilaksanakan LPSK akan dibantu oleh berbagai instansi terkait terutama instansi pemerintah. Hal ini memang sudah seharusnya diberikan. Karena sudah menjadi platform umum, bahwa masalah yang terkait dengan perlindungan korban, saksi dan/atau pelapor tindak pidana hanya bisa ditangani secara efektif melalui pendekatan multi Lembaga .LPSK dengan jelas harus membangun posisi kelembagaan yang berada diantara dua kepentingan yaitu kepentingan pertama yang dimandatkan oleh UU No.31 Tahun 2014 sebagai Lembaga yang bersifat mandiri dan independent. Dan diharapkan hubungan serta koordinasi antar Lembaga yang berwenang nantinya relative tidak menjadi kendala ketika dijadikan implementasi pelaporan dan perlindungan kepada seorang whistleblower.

\section{SIMPUL DAN SARAN}

\section{Simpulan}

Dari isi tulisan diatas dapat ditarik sebuah kesimpulan bahwa pengaturan perlindungan hukum terhadap whistleblower dalam tindak pidana narkotika masih tersebar di beberapa peraturan perundangundangan dan secara implisit diatur dalam UU No. 13 Tahun 2006 jo UU No 31 Tahun 2014 sehingga tidak memperoleh jaminan perlindungan dan keamanan hukum yang memadai terhadap whistleblower. Bentuk keamanan hukum kepada whistleblower penyalahgunaan tindak pidana narkotika adalah perlindungan atau keamanan terhadap fisik. Psikis, perlindungan hukum serta penghargaan, serta Konsep perlindungan hukum terhadap whistleblower dalam tindak pidana narkotika di masa mendatang meliputi lembaga perlindungan dan model perlindungan. Dalam konteks lembaga perlindungan, jika tetap mempertahankan LPSK perlu diperluas kewenangannya atau membentuk lembaga perlindungan baru yang bersifat rnandiri dan independen yang mengatur khusus whistleblower tersebut.

\section{Saran}

Untuk kesempurnaan dan tercapainya luaran dari karya ini, penulis menyarankan agar model perlindungan terhadap whistleblower dapat berupa tipe hak-hak prosedural dan model partisipasi langsung atau aktif (the procedural rights model partie civile model/civil action system) model pelayanan atau model partisipasi secara tidak langsung atau model pasif (the services model) model perlindungan persuasif atau partisipatif model perlindungan komprehensif dan model perlindungan melalui teleconference. Upaya yang dapat dilakukan oleh Pemerintah aitu perlu dibuatkan peraturan perundangan-undangan yang baru sebagai penyempurnaan UU No. 13 Tahun 2006 Jo UU No. 31 Tahun 2014 yang mengatur secara khusus terkait dengan perlindungan hukum terhadap whistleblower.

\section{DAFTAR PUSTAKA}

Astri, I. L., Sunaryo, S., \& Jatmiko, B. D. W. (n.d.). Perlindungan Hukum Terhadap Justice Collaborator dalam Tindak Pidana Narkotika. Indonesia Law Reform Journal, Vol.1 (1).

Eleanora, F. N. (2011). Bahaya Penyalahgunaan Narkoba Serta Usaha Pencegahan dan Penanggulangannya. Jurnal Hukum Fakultas Hukum Unissula, Vol 25(1).

H, M. (2008). Penyalahgunaan Narkoba Dalam Perspektif Hukum Islam Dan Hukum Pidana Nasional. PT. Raja Grafindo Persada.Jakarta.

Mulyadi, L. (2007). Hukum Acara Pidana Normatij, Teoritis, Praktik dan Permasalahannya. Jakarta. Mulyadi, L. (2007). Hukum Acara Pidana Normatij, Teoritis, Praktik dan Permasalahannya. Jakarta. Raharjo, S. (2000). Ilmu Hukum. PT. Citra Aditya Bakti. Bandung.

Soedjono, A. (2000). Patologi Sosial. Alumni Bandung.

Sitanggang, B. A. (1999). Pendidikan Pencegahan Penyalahgunaan Narkotika. Karya Utama. Jakarta.

Widodo, S. (2007). Lembaga Perlindungan Saksi dan Korban di Indonesia. Jakarta. Yusuf, M. (2011). Urgensi Perlunya Memberikan Perlindungan Terhadap Saksi. 